JAMP: Jurnal Adminitrasi dan Manajemen Pendidikan

Volume 1 Nomor 3 September 2018, Hal : 302-312

Tersedia Online di http://journal2.um.ac.id/index.php/jamp/

ISSN 2615-8574 (online)

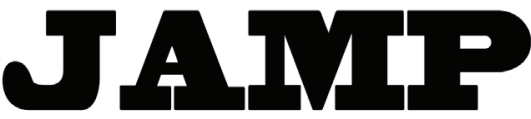

JURNAL ADMINISTRASI DAN MANAJEMEN PENDIDIKAN

\title{
MANAJEMEN PROGRAM PENGUATAN PENDIDIKAN KARAKTER DI SEKOLAH DASAR
}

\author{
Atik Maisaro \\ Bambang Budi Wiyono \\ Imron Arifin \\ atikmaisaro19@gmail.com \\ Universitas Negeri Malang, Jl. Semarang No. 5 Malang 65145
}

\begin{abstract}
The purpose of this research to describe the management of character education strengthening at elementary school. This research used qualitative approach with a case study design. It was conducted at Elementary School Bunulrejo 2 Malang. Data were collected employing observation, interviews, and documentation. This was carried out through three steps: data condensation, presentation, and conclusions. This research shows: (1) the character education strengthening was planned imvolving six stages namely observation, coordination meeting, arranging work program, program implementation, supervision, and evaluation, (2) the principal was assisted by school development team and coordinator, 3) the programs were implemented through four steps: program integration, culture development, exemplary, and cooperation with parents, (4) direct program supervisions, (5) program evaluation including planning, supervising, data processing, and refinement meeting.
\end{abstract}

Keywords: management, strengthening, character education, elementary school

\begin{abstract}
Abstrak : Tujuan penelitian ini yaitu mendeskripsikan manajemen program penguatan pendidikan karakter di Sekolah Dasar. Jenis penelitian yang digunakan adalah penelitian studi kasus dengan menggunakan pendekatan kualitatif. Penelitian ini dilaksanakan di SD Negeri Bunulrejo 2 Malang. Teknik pengumpulan data yang digunakan berupa observasi, wawancara, dan dokumentasi. Tahapan analisis data menggunakan tiga langkah yaitu: kondensasi data, menyajikan data, dan menarik kesimpulan. Simpulan penelitian ini menunjukkan: (1) perencanaan program penguatan pendidikan karakter memiliki beberapa tahapan, yaitu observasi, rapat koordinasi, menyusun program kerja, pelaksanaan program, pengawasan, serta evaluasi, (2) kepala sekolah dibantu oleh tim pengembang sekolah dan koordinator sekolah, (3) pelaksanaan program melalui empat tahap kegiatan, yaitu pengintegrasian, pembudayaan, keteladanan, dan kerjasama dengan orang tua, (4) proses pengawasan program bersifat langsung, (5) evaluasi program melalui empat tahapan yaitu menyusun rencana evaluasi, mengawasi, mengolah data, dan rapat perbaikan.
\end{abstract}

Kata Kunci : manajemen, penguatan, pendidikan karakter, sekolah dasar

Pendidikan sebagai upaya menyiapkan peserta didik bagi perannya di masa mendatang, mempunyai peran yang sangat strategis dalam meningkatkan kualitas sumber daya manusia dan upaya mewujudkan cita-cita bangsa Indonesia. Pendidikan yang dimaksud harus sesuai dengan pencapaian tujuan yang telah dirumuskan dalam Undang-Undang Republik Indonesia Nomor 20 Tahun 2003 tentang Sisdiknas Pasal 3 yang berbunyi: Pendidikan nasional berfungsi mengembangkan kemampuan dan membentuk watak serta peradaban bangsa yang bermartabat dalam rangka mencerdaskan kehidupan bangsa, bertujuan untuk berkembangnya potensi peserta didik agar menjadi manusia yang beriman dan bertaqwa kepada Tuhan Yang Maha Esa, berakhlak mulia, sehat, berilmu, cakap, kreatif, mandiri, dan menjadi warga negara yang demokratis serta bertanggungjawab. 
Berdasarkan Undang-Undang tersebut menyatakan bahwa pendidikan berfungsi untuk membentuk watak. Watak inilah yang disebut sebagai karakter. Pendidikan karakter memiliki peran penting dalam pembentukan moral. Menurut Lickona (dalam Isnaini, 2016:36) karakter berkaitan dengan konsep moral, sikap moral, dan perilaku moral. Berdasarkan tiga komponen tersebut maka dapat disimpulkan bahwa karakter yang baik didukung oleh pengetahuan tentang kebaikan, keinginan untuk berbuat baik, serta melakukan perbuatan yang baik.

Penguatan Pendidikan Karakter merupakan kelanjutan dan revitalisasi gerakan nasional pendidikan karakter yang telah dimulai pada 2010. Penguatan pendidikan karakter (character education) atau pendidikan moral (moral education) dalam masa ini perlu diimplementasikan untuk mengatasi krisis moral yang sedang melanda negeri ini. Krisis tersebut antara lain adalah pergaulan bebas yang semakin meningkat, seperti penyalahgunaan obat-obatan terlarang (narkoba) dan pornografi. Selain dua kasus tersebut, saat ini juga marak terjadi kekerasan terhadap anak dan remaja, pencurian, kebiasaan menyontek, serta tawuran yang sudah menjadi masalah sosial yang sampai saat ini belum dapat diatasi secara tuntas.

Selain persoalan yang mengancam keutuhan serta masa depan bangsa, Indonesia juga menghadapi tantangan dan persaingan di pentas global. Misalnya rendahnya indeks pembangunan individu Indonesia yang mengancam daya saing bangsa, lemahnya fisik anak-anak Indonesia karena kurangnya olah raga, rendahnya rasa seni dan estetika serta pemahaman etika yang belum terbentuk selama masa pendidikan. Dari berbagai alasan tersebut telah cukup menjadi dasar yang kuat untuk menguatkan jati diri dan identitas bangsa melalui gerakan nasional pendidikan dengan meluncurkan Gerakan Penguatan Pendidikan Karakter yang diterapkan pada jenjang pendidikandasar dan menengah.

Hadirnya penguatan pendidikan karakter memiliki peran yang sangat penting, karena perubahan perilaku peserta didik (sebagai hasil dari proses pendidikan karakter) sangat ditentukan oleh faktor lingkungan. Dengan kata lain, pembentukan dan lingkungan yang mencakup diantaranya lingkungan fisik dan budaya sekolah, manajemen sekolah, kurikulum, pendidik, dan metode mengajar.

Pembentukan karakter melalui faktor lingkungan dapat dilakukan melalui beberapa strategi, antara lain yaitu keteladanan, intervensi, pembiasaan yang dilakukan secara konsisten dan penguatan. Dengan kata lain, perkembangan dalam pembentukan karakter memerlukan keteladanan yang ditularkan, intervensi melalui proses pembelajaran, pelatihan, pembiasaan terus-menerus dalam jangka panjang yang dilakukan secara kontinyu dan penguatan, serta harus diimbangi dengan nilai-nilai luhur. Hal tersebut sesuai dengan prinsip PPK dalam Peraturan Presiden Republik Indonesia Nomor 87 Tahun 2017 tentang Penguatan Pendidikan Karakter pasal 5 yang berbunyi: (a) berorientasi pada berkembangnya potensi peserta didik secara menyeluruh dan terpadu, (b) keteladanan dalam penerapan pendidikan karakter pada masing-masing lingkungan pendidikan, dan (c) berlangsung melalui pembiasaan dan sepanjang waktu dalam kehidupan sehari-hari.

Pola pembentukan karakter pada setiap instansi pendidikan cukup bervariasi, hal tersebut disebabkan oleh adanya perbedaan peraturan yang telah diterapkan dengan kondisi masing-masing instansi pendidikan tersebut, karena setiap instansi memiliki pembinaan, pengasuh dan peserta didik yang berbeda. Salah satu instansi pendidikan yang menerapkan program penguatan pendidikan karakter adalah SD Negeri Bunulrejo 2 Malang. Pembinaan karakter peserta didik di SD Negeri Bunulrejo 2 Malang memiliki empat kegiatan yang dilaksanakan secara berkesinambungan dan kontiyu. Kegiatan tersebut antara lain yaitu pengintegrasian, pembudayaan, keteladanan, serta kerja sama dengan orang tua. Kegiatan tersebut dilaksanakan secara berdampingan guna mencapai tujuan program penguatan pendidikan karakter sesuai dengan yang diharapkan.

Sasaran dalam program penguatan pendidikan karakter ini yakni peserta didik. Guru dan staf sekolah berperan untuk keteladanan bagi peserta didik, maksudnya adalah guru dan staf menjadi contoh yang baik untuk peserta didik guna memperkuat karakter peserta didik itu sendiri.

Secara etimologis, kata manajemen merupakan terjemahan dari bahasa inggris management. Management sendiri berasal dari kata to manage yang berarti mengelola. Dalam pengertian manajemen mengandung dua jenis kegiatan, yaitu kegiatan pikir dan kegiatan tingkah laku (Sahertian dalam 
Imron, 2012). Manajemen sebagai proses perencanaan, pengoganisasian pengisian staf, pimpinan, serta pengontrolan untuk optimasi penggunaan sumber-sumber pelaksanaan tujuan organisasi secara efektif dan efisien (Hidayatullah, 2010). Manajemen merupakan suatu proses dalam rangka mencapai tujuan dengan cara bekerjasama dengan orang-orang serta organisasi lainnya.

Manajemen pada dasarnya memiliki tingkatan baik struktur maupun kewenangan serta fungsi yang dimiliki. Perencanaan berkaitan dengan rangkaian kegiatan yang akan dilaksanakan guna mencapai tujuan di masa yang akan datang (Sudjana, 2004). Perencanaan merupakan proses kegiatan rasional dan sistematis dalam rangka menetapkan keputusan, kegiatan, atau langkah-langkah yang akan dilaksanakan guna mencapai tujuan yang efektif dan efisien (Mulyono, 2010). Jadi dalam langkah ini, melibatkan pemetaan yang tepat untuk mencapai suatu tujuan tertentu. Langkah-langkah ini diperlukan guna mengembangkan suatu rencana. Ketika rencana itu ditempatkan, baru dapat ditindaklanjuti untuk mencapai tujuan organisasi.

Pengorganisasian merupakan fungsi kedua dalam manajemen dan dapat diartikan sebagai proses kegiatan penyusunan struktur organisasi sesuai dengan tujuan, sumber, serta lingkungannya. Pengorganisasian merupakan tindakan mengusahakan hubungan tingkah laku yang efektif antar individu, guna mencapai tujuan sasaran tertentu (Terry dalam Hasibuan, 2011).

Fungsi penggerakan merupakan pelaksanaan dari kegiatan perencanaan dan pengorganisasian (Amtu, 2013). Penekanan dari fungsi pelaksanaan adalah penciptaan kerja sama antar anggota organisasi serta peningkatan semangat kerja keseluruhan anggota guna tercapainya tujuan organisasi. Kegiatan pengarahan dan bimbingan sebagai perwujudan fungsi pelaksanaan dalam manajemen memerlukan penciptaan serta pengembangan komunikasi secara efektif dan efisien. Fungsi pelaksanaan merupakan implementasi dari pengarahan, tetapi juga biasanya berlangsung secara serempak. Fungsi-fungsi manajemen tidak bisa dipisahkan antara yang satu dengan yang lain karena membentuk suatu mata rantai yang tersambung dalam suatu proses pengolahan organisasi.

Fungsi pengawasan ini sangat penting dan sangat menentukan pelaksanaan proses manajemen, peranan pengawasan juga sangat menentukan baik atau buruknya suatu rencana, oleh karena itu harus dilakukan dengan sebaik-baiknya. Pengawasan diartikan sebagai proses mengukur serta menilai tingkat efektivitas kinerja organisasi serta tingkat efisiensi penggunaan sarana kerja pada pencapaian tujuan organisasi (Amtu, 2013).

Untuk memperoleh informasi yang tepat, dalam kegiatan evaluasiyang di dalamnya termasuk evaluasi pembelajaran, diperlukan dasar informasi yang akurat, yang dapat dicapai melalui kegiatan pengukuran (Wiyono dan Sunarni, 2009). Hakikat evaluasi yaitu suatu proses yang sistematis dan berkelanjutan guna menentukan kualitas (nilai dan arti) daripada sesuatu, berdasarkan atas pertimbangan, dan kriteria tertentu dalam rangka mengambil keputusan (Kurniadin dan Machali, 2012).

Pada hakikatnya, pendidikan bukan hanya memberikan ilmu pengetahuan saja, tetapi juga memberikan ilmu yang mengasah intelektual. Pendidikan juga harus menciptakan generasi berkarakter yang tercermin pada perilaku seseorang dalam kehidupannya. Karakter berasal dari bahasa Yunani "charassein" yang berarti mengukir. Maksudnya ialah membentuk karakter diibaratkan seperti mengukir sebuah batu permata atau permukaan besi yang keras. Maka dari itu, berkembanglah pengertian karakter yang didefinisikan sebagai tanda khusus atau pola perilaku (Bohlin dkk dalam Judiani, 2010). Sedangkan menurut Kamus Besar Bahasa Indonesia, karakter didefinisikan sebagai sifat-sifat kejiwaan, akhlak, atau budi pekerti yang membedakan antara individu satu dengan yang lainnya. Berdasarkan pendapat di atas dapat disimpulkan bahwa karakter merupakan sifat yang mantap dan stabil, yang melekat dalam diri seseorang, sehingga berbeda antara satu individu dengan individu lainnya.

Dari konsep karakter tersebut, kemudian muncullah istilah pendidikan karakter. Pendidikan karakter merupakan sebuah usaha mendidik anak agar dapat mengambil keputusan dengan bijak dan mempraktikannya dalam kehidupan sehari-hari sehingga dapat memberikan nilai positif kepada lingkungannya (Megawangi dalam Kesuma dkk, 2012). Pembangunan karakter perlu dilaksanakan oleh setiap individu. Pembangunan karakter merupakan salah satu tujuan dari sistem pendidikan di Indonesia. Pendidikan karakter seharusnya membawa peserta didik ke dalam pengenalan nilai secara 
kognitif, penghayatan nilai secara afektif, serta ke pengamalan nilai secara nyata (Buhori dalam Kurniawan, 2017). Pendidikan karakter dilaksanakan melalui pendidikan nilai-nilai atau kebajikan yang menjadi dasar nilai karakter bangsa. Oleh karenanya, pendidikan karakter pada dasarnya merupakan pengembangan nilai yang berasal dari pandangan hidup atau ideologi bangsa, agama, budaya, dan nilai yang terumuskan dalam tujuan pendidikan nasional.

Pemerintah melalui Kemendikbud mencanangkan Program Penguatan Pendidikan Karakter (Program PPK) di sekolah. Definisi dari Penguatan Pendidikan Karakter (PPK) dalam Perpres Nomor 87 Tahun 2017 yakni: Gerakan pendidikan di bawah tanggung jawab satuan pendidikan untuk memperkuat karakter peserta didik melalui harmonisasi olah hati, olah rasa, olah pikir, dan olah raga dengan pelibatan dan kerja sama antara satuan pendidikan, keluarga, dan masyarakat, sebagai bagian dari Gerakan Nasional Revolusi Mental (GNRM).

Untuk menciptakan program Penguatan Pendidikan Karakter di sekolah, perlu adanya kerja sama antara kepala sekolah dengan guru guna mengimplementasikannya dalam kegiatan pembelajaran. Tugas kepala sekolah ialah mendesain budaya sekolah guna menjadi ciri khas dan keunggulan sekolah, sedangkan tugas guru adalah mengintegrasikan nilai-nilai karakter dalam pembelajaran di kelas serta mampu mengelola manajemen kelas agar program penguatan pendidikan karakter dapat terwujud (Rumah Juara, 2017).

Adapun lima nilai utama yang saling berkesinambungan dalam membentuk jejaring nilai karakter yang perlu dikembangkan sebagai prioritas dalam gerakan PPK. Lima nilai utama tersebut yaitu religius, nasionalis, gotong royong, kemandirian, dan integritas.

Nilai karakter religius mencerminkan keberimanan terhadap Tuhan Yang Maha Esa. Adapun subnilai religius antara lain yakni cinta damai, toleransi, menghargai perbedaan agama dan kepercayaan anti bullying dan kekerasan. Nilai karakter nasionalis merupakan cara berpikir dan bersikap yang menunjukkan kepedulian dan penghargaan terhadap bahasa, lingkungan, sosial, budaya, ekonomi, dan politik bangsa. Subnilai nasionalis antara lain yakni rela berkorban, unggul, dan berprestasi, cinta tanah air, menjaga lingkungan, taat hukum, disiplin, menghormati keberagaman budaya, suku, dan agama. Nilai karakter mandiri merupakan sikap dan perilaku tidak bergantung pada orang lain. Subnilai mandiri antara lain yakni etos kerja (kerja keras), profesional, dan kreatif. Nilai karakter gotong royong mencerminkan tindakan menghargai semangat kerja sama dalam menyelesaikan persoalan bersama dan memberi bantuan/pertolongan pada orang-orang yang membutuhkan. Subnilai gotong royong antara lain yakni menghargai, kerja sama, komitmen atas keputusan bersama, musyawarah mufakat, tolong menolong, dan solidaritas. Nilai karakter integritas merupakan nilai yang mendasari perilaku guna menjadikan dirinya sebagai orang yang dapat dipercaya. Subnilai integritas antara lain yakni kejujuran, anti korupsi, keadilan, dan tanggung jawab.

Lima nilai utama penguatan pendidikan karakter tersebut berdasarkan Perpres Nomor 87 tahun 2017 tentang Penguatan Pendidikan Karakter dapat dilihat pada Gambar 1.

\section{METODE}

Penelitian ini menggunakan pendekatan kualitatif karena ingin menggali informasi secara mendalam mengenai manajemen program penguatan pendidikan karakter. Penelitian kualitatif merupakan metode penelitian yang digunakan untuk meneliti kondisi obyek alamiah, dan peneliti sebagai instumen kunci (Sugiyono, 2013). Adapun jenis penelitian yang digunakan yakni penelitian studi kasus, karena peneliti ingin mengetahui fakta mendalam dan menemukan fakta tentang manajemen program penguatan pendidikan karakter.

Kehadiran peneliti di lokasi sudah diketahui oleh Kepala SD Negeri Bunulrejo 2 Malang. Peneliti datang di lokasi penelitian pada hari Senin 29 Januari 2018 untuk meminta izin akan melakukan penelitian di SD Negeri Bunulrejo 2 Malang secara informal, kemudian setelah pihak sekolah menyatakan menerima, peneliti kembali ke sekolah tanggal 12 Februari untuk menyerahkan surat pengantar dari Fakultas serta Dinas Pendidikan Kota Malang kepada sekolah. Setelah itu peneliti memperkenalkan diri 
kepada subyek penelitian, membuat jadwal pertemuan dan melaksanakan penelitian yaitu observasi, wawancara, serta dokumentasi untuk mengumpulkan data-data yang dibutuhkan.

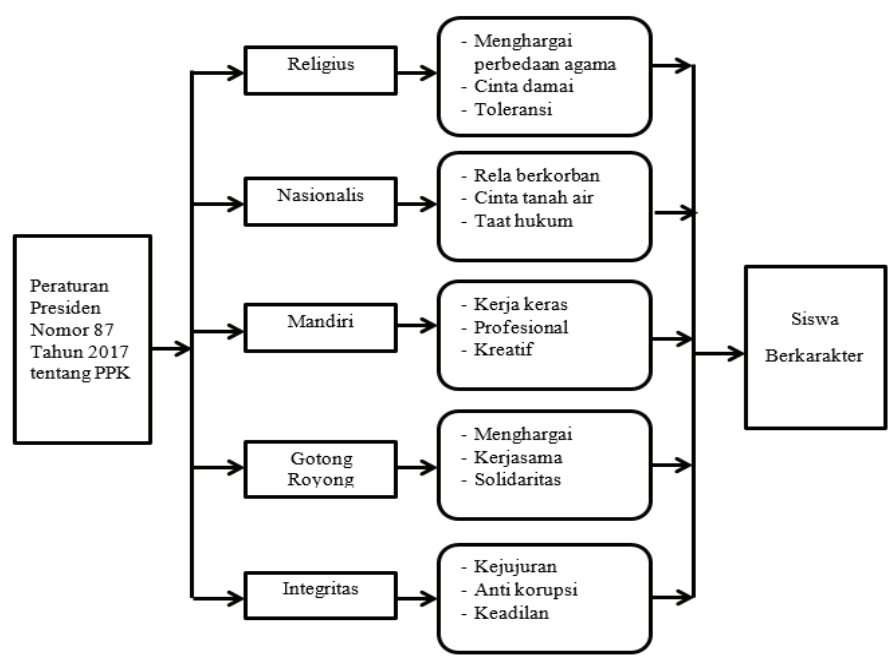

Gambar 1 Bagan Nilai Utama Penguatan Pendidikan Karakter

Lokasi penelitian ini dilakukan di SD Negeri Bunulrejo 2 Malang yang beralamatkan di Jalan Bedadung Nomor 03, Kecamatan Blimbing, Kota Malang dengan nomor telepon (0341) 486483 dan mempunyai situs webblog: sdnbunulrejoduamalang.blogspot.com. Letak SD Negeri Bunulrejo 2 berada di jalan Bedadung yang merupakan satu komplek perumahan, terletak di depan suatu lapangan komplek yang biasa disebut lapangan Sanan Sari. Lapangan tersebut merupakan lapangan milik warga yang diperbolehkan untuk dipergunakan oleh sekolah untuk kegiatan olahraga maupun ekstrakurikuler. SD negeri Bunulrejo 2 Malang merupakan salah satu SD Negeri favorit di Kota Malang dengan visi yaitu "Beriman, Bertaqwa, Berbudi luhur, Cerdas, Menguasai IPTEK, Peduli lingkungan, Cinta tanah air dan bangsa." Dari hal tersebut sudah terlihat penanaman karakter sejak dini di SD Negeri Bunulrejo 2 Malang. Adapun jumlah peserta didik untuk tahun ajaran 2016/2017 adalah 587 siswa yang dibagi menjadi 18 rombel. Rata-rata tiap rombel diisi oleh 30 hingga 40 siswa.

Sumber data yang digunakan dalam penelitian kualitatif ini yaitu kata-kata atau ucapan yang didapat melalui wawancara dan catatan yang didapat dari observasi pada subyek serta dokumentasi dari dokumen-dokumen yang relevan dengan fokus penelitian yang diteliti. Sumber primer dari penelitian ini adalah Kepala SD Negeri Bunulrejo 2 Malang sebagai informan kunci. Sedangkan sumber sekunder yaitu informan pendukung/tambahan yang dianggap mengetahui tentang informasi yang diperlukan, yaitu koordinator kurikulum, koordinator mutu, serta wali murid di SD Negeri Bunulrejo 2 Malang.

Penelitian ini menggunakan beberapa prosedur pengumpulan data, antara lain yaitu observasi, wawancara, dan studi dokumentasi. Data yang dikumpulkan berkaitan dengan: (1) perencanaan penguatan pendidikan karakter, (2) pengorganisasian penguatan pendidikan karakter, (3) pelaksanaan penguatan pendidikan karakter, (4) pengawasan penguatan pendidikan karakter, dan (5) evaluasi penguatan pendidikan karakter di SD Negeri Bunulrejo 2 Malang. Analisis data dalam penelitian kualitatif ialah proses sistematis guna mencari dan mengatur transkrip wawancara, catatan lapangan, serta materi-materi lain untuk menemukan apa yang penting dilaporkan kepada orang lain sebagai temuan penelitian (Ulfatin, 2015). Tahapan dalam analisis data yang peneliti lakukan sesuai dengan teori Miles, Huberman dan Saldana (2014) yaitu menganalisis data dengan menggunakan tiga langkah yakni kondensasi data (data condensation), menyajikan data (data display), dan menarik simpulan atau verifikasi (conclusing drawing and verification). 


\section{HASIL}

\section{Perencanaan Program Penguatan Pendidikan Karakter}

Dasar perencanaan program penguatan pendidikan karakter yakni aturan pemerintah tentang penguatan pendidikan karakter, observasi, dan mendata. Dasar perencanaan pendidikan karakter tersebut dapat dijabarkan sebagai berikut: (1) aturan pemerintah tentang penguatan pendidikan karakter, yaitu Peraturan Presiden Republik Indonesia nomor 87 tahun 2017 tentang Penguatan Pendidikan Karakter, (2) berdasarkan observasi lapangan, observasi disini dibagi menjadi tiga, yaitu observasi berdasarkan kondisi lingkungan sekolah, observasi berdasarkan sumber daya manusia (Tenaga pendidik dan kependidikan) dan observasi terhadap hasil tingkah laku peserta didik, (3) Membuat atau mengolah data. Data disini tidak hanya diartikan pendidikan budi pekerti, tetapi juga berhubungan dengan bakat minat peserta didik, sehingga perumusan pendidikan karakter dapat dicapai sesuai tujuan.

Selanjutnya yaitu tahapan perencanaan program penguatan pendidikan karakter yang terdiri dari yang pertama yaitu observasi, guna untuk mengetahui bagaimana kondisi lingkungan sekolah dan juga peserta didik. Kedua yaitu rapat koordinasi untuk memilih tim, dari semua koordinator sekolah, dipilih koordinator inti yang disebut tim pengembang sekolah. Ketiga yaitu menyusun program kerja, yang dibantu oleh koordinator inti atau tim pengembang sekolah. Keempat yaitu pelaksanaan program, pengawasan, yakni realisasi dari program kerja. Kelima yaitu evaluasi, guna meningkatkan mutu program agar lebih baik dari sebelumnya.

\section{Pengorganisasian Program Penguatan Pendidikan Karakter}

Sebuah lembaga tentunya membutuhkan suatu organisasi agar lebih terkoodinasikan dengan baik, hal tersebut guna mempermudah lembaga dalam melaksanakan perencanaan yang telah disepakati sebelumnya. Kepala sekolah sebagai penanggungjawab kegiatan, dibantu oleh tim pengembang sekolah dan juga para koordinator. Adapun koordinator tersebut adalah koordinator kesiswaan, koordinator sarana dan prasarana, koordinator hubungan sekolah dengan masyarakat, dan lain-lain. adapun penjabaran dari kepengurusan program penguatan pendidikan karakter adalah sebagai berikut: (1) kepala sekolah, sebagai penanggungjawab kegiatan, dan kebijakan sekolah, (2) tim pengembang sekolah, yang terdiri dari koordinator kurikulum dan pengembang mutu sekolah, yaitu membantu kepala sekolah dalam mengawasi, membuat program kerja, dan membantu berjalannya program kegiatan, (3) koordinator sekolah, turut membantu tim pengembang sekolah.

\section{Pelaksanaan Program Penguatan Pendidikan Karakter}

Kegiatan pelaksanaan program penguatan pendidikan karakter merupakan realisasi dari perencanaan yang telah ditetapkan sebelumnya. Adapun kegiatan pelaksanaan program penguatan pendidikan karakter di SD Negeri Bunulrejo 2 Malang ini ialah: (1) pengintegrasian, guna menyesuaikan dengan program sekolah sebelumnya, (2) pembudayaan, dapat diartikan dengan kegiatan pembiasaan yang mengandung unsur lima nilai utama penguatan pendidikan karakter, diantaranya yaitu religius, nasionalisme, gotong royong, kemandirian, dan integritas, (3) keteladanan, diharapkan peserta didik dapat mencontoh hal yang baik yang telah diajarkan atau dicontohkan oleh para guru di sekolah, (4) kerjasama dengan orang tua peserta didik, guna mengikuti program sekolah serta memberi dukungan atas berjalannya program penguatan pendidikan karakter tersebut.

\section{Pengawasan Program Penguatan Pendidikan Karakter}

Pengawasan dilakukan dengan menggunakan teknik observasi. Kepala sekolah juga melakukan pengawasan dengan supervisi sehingga dapat mengetahui bagaimana kinerja guru dalam pembelajaran di kelas, sehingga dapat dijadikan evaluasi untuk kedepannya agar lebih baik. Guru mempunyai tanggung jawab untuk mengawasi peserta didik disaat pembelajaran berlangsung.

Pengawasan yang dilakukan oleh kepala sekolah dalam hal meninjau kembali program kerja yang telah dilaksanakan, bertujuan untuk meningkatkan dan/atau mempertahankan program kegiatan penguatan pendidikan karakter yang telah dilakukan. Apabila ada yang kurang berkenan maka kepala sekolah tidak segan-segan untuk menegur guna meningkatkan program agar kedepannya dapat lebih baik. 


\section{Evaluasi Program Penguatan Pendidikan Karakter}

Setelah dilakukannya pengawasan, tentunya tahap selanjutnya adalah evaluasi, guna untuk memperbaiki program sebelumnya, sehingga kedepannya bisa menjadi lebih baik. Begitu pula dengan program penguatan pendidikan karakter di SD Negeri Bunulrejo 2 Malang. Adapun kegiatan dalam evaluasi meliputi menyusun rencana evaluasi, disaat berlangsungnya kegiatan, kepala sekolah mengawasi (supervisi) guna mengumpulkan data, mengolah dan menganalisis data, serta mengadakan rapat, untuk mencari solusi dari masalah tersebut, agar kegiatan selanjutnya dapat lebih baik.

Manajemen program penguatan pendidikan karakter dilaksanakan mulai dari perencanaan sampai evaluasi guna mencapai tujuan siswa berkarakter yang menerapkan lima nilai penguatan pendidikan karater. Temuan manajemen program pendidikan karakter di SD negeri Bunulrejo 2 Malang dapat dilihat pada Gambar 2.

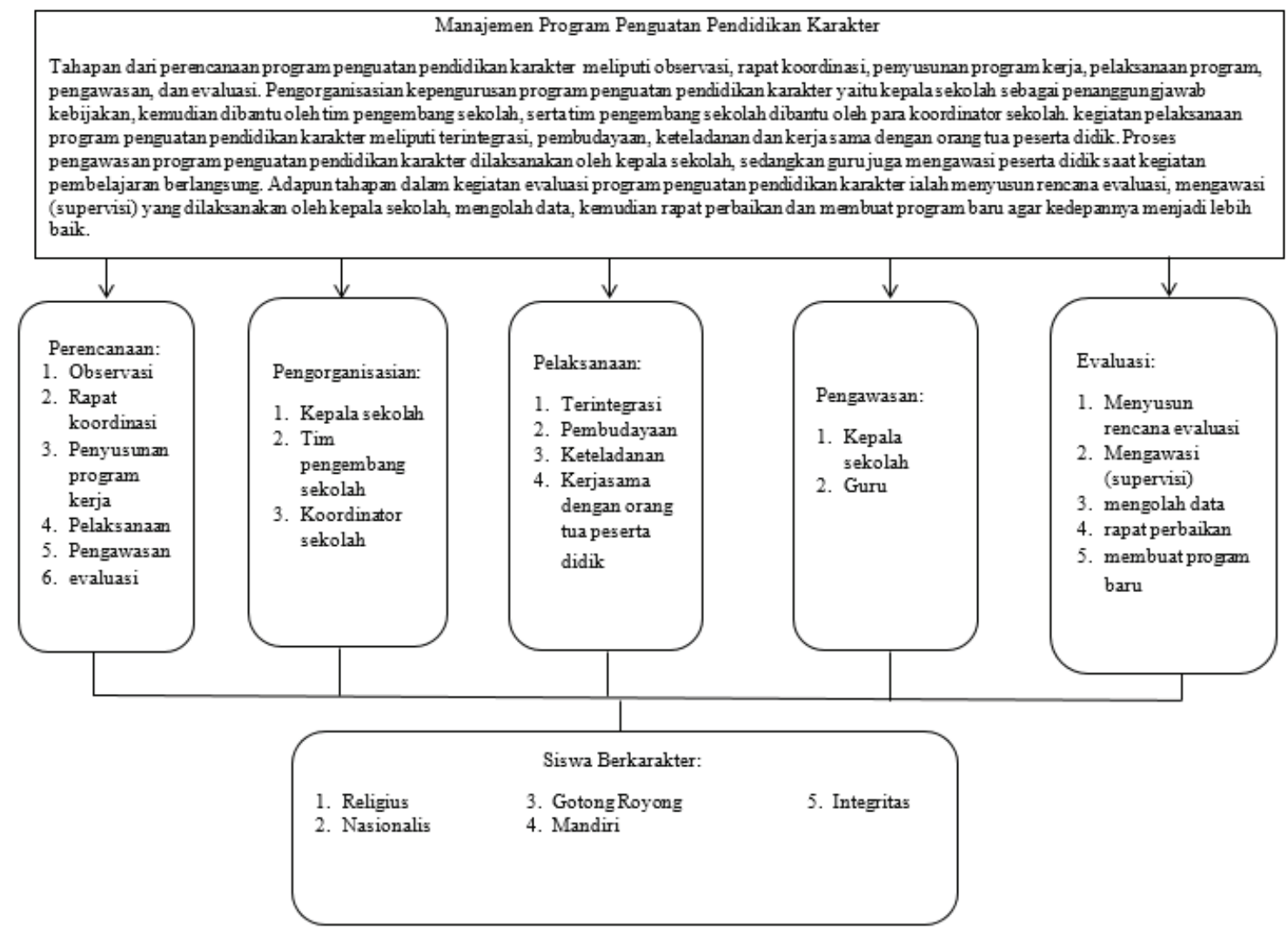

Gambar 2 Bagan Temuan Penelitian Manajemen Program Penguatan Pendidikan Karakter

\section{PEMBAHASAN}

\section{Perencanaan Program Penguatan Pendidikan Karakter}

Perencanaan program penguatan pendidikan karakter di SD Negeri Bunulrejo 2 Malang memiliki beberapa tahapan, yaitu observasi, rapat koordinasi, menyusun program kerja, pelaksanaan program, pengawasan, serta evaluasi. Hal tersebut dilaksanakan guna mencapai tujuan yang disepakati. Observasi dilakukan guna mengetahui bagaimana kondisi lingkungan sekolah dan peserta didik. Rapat koordinasi dilakukan untuk pemilihan tim, yang disebut tim pengembang sekolah. penyusunan program kerja dilaksanakan, dan dibantu oleh tim pengembang sekolah serta koordinator inti. Setelah itu yakni pelaksanaan program yang diikuti oleh pengawasan, guna mengetahui proses kerja sudah sesuai dengan prosedur yang ditentukan sebelumnya, dan tahap yang terakhir yaitu evaluasi, diharapkan dapat meningkatkan mutu program agar lebih baik dari sebelumnya. 
Perencanaan berkaitan dengan rangkaian kegiatan yang akan dilaksanakan guna mencapai tujuan di masa yang akan datang (Sudjana, 2004). Perencanaan merupakan proses dari kegiatan rasional dan sistematis dalam menetapkan segala keputusan, kegiatan, atau langkah-langkah yang akan dilaksanakan di kemudian hari dalam rangka mencapai tujuan yang efektif dan efisien (Mulyono, 2010).

Dari pengertian di atas dapat disimpulkan bahwa dalam suatu perencanaan selalu ada tahapantahapan guna mencapai tujuan yang efektif dan efisien dalam suatu lembaga pendidikan. Tahapan tersebut meliputi adanya proses manajemen mulai dari perencanaan sampai dengan evaluasi.

Dalam merencanakan program penguatan pendidikan karakter di SD Negeri Bunulrejo 2 Malang ini melibatkan beberapa pihak, antara lain: pendidik, tenaga kependidikan, komite, dan perwakilan dari Dinas Pendidikan yaitu pengawas. Keterlibatan pihak-pihak tersebut tentunya sangat penting untuk menunjang keberhasilan program penguatan pendidikan karakter di SD Negeri Bunulrejo 2 Malang.

Keefektifan perencanaan sekolah harus menghasilkan program yang luwes serta berpusat pada peserta didik, yang mencakup program pembelajaran, pengajaran, pengembangan kurikuler, kegiatan peserta didik, keuangan sekolah, elaborasi kurikulum menjadi bahan pengajaran, gedung sekolah, laboratorium, perpustakaan, serta hubungan sekolah dengan masyarakat (Sagala, 2012). Oleh karena itu, perencanaan dikatakan efektif jika kepala sekolah melibatkan guru guna bekerja sama dalam upaya mengefektifkan program-program sekolah melalui usaha kolektif bersama guru guna mencapai tujuan yang telah ditentukan.

Berdasarkan penjelasan tersebut sudah sesuai dengan teori yang telah dijabarkan. Sehingga dapat disimpulkan bahwa perencanaan program pendidikan karakter melibatkan beberapa pihak antara lain pendidik, tenaga pendidikan, komite, dan pengawas guna menunjang pelaksanaan program penguatan pendidikan karakter. Serta memiliki tahapan perencanaan mulai dari observasi sampai dengan evaluasi guna mencapai tujuan program penguatan pendidikan karakter secara efektif dan efisien.

\section{Pengorganisasian Program Penguatan Pendidikan Karakter}

Suatu lembaga tentunya membutuhkan organisasi agar lebih terkoordinasikan dengan baik segala sesuatunya. Sebab, hal tersebut mempermudah lembaga dalam melaksanakan perencanaan yang ada. Berdasarkan temuan penelitian di SD Negeri Bunulrejo 2 Malang tentang manajemen program penguatan pendidikan karakter, kepala sekolah sebagai penanggungjawab kegiatan, dibantu oleh tim pengembang sekolah, dan juga para koordinator.

Pengorganisasian merupakan tindakan mengusahakan hubungan yang efektif antar individu, sehingga mereka dapat bekerja sama secara efisien, dengan demikian memperoleh kepuasan pribadi dalam hal melaksanakan tugas dalam kondisi lingkungan guna mencapai tujuan sasaran tertentu (Terry dalam Hasibuan, 2011). Organisasi merupakan suatu sistem interaksi antar individu yang ditujukan untuk mencapai tujuan organisasi, dimana sistem tersebut memberikan arahan perilaku untuk anggota organisasi (Tim Dosen Administrasi pendidikan Universitas Pendidikan Indonesia, 2012). Definisi ini menekankan pada keharusannya sebuah organisasi didasarkan pada interaksi sosial dimana anggotanya dan anggota dengan lingkungannya agar tujuan organisasi dapat dicapai secara efektif dan efisien. Pengorganisasian mengandung tiga elemen yaitu bekerja sama, pencapaian tujuan, dan komunikasi (Barnard dalam Septiani, 2012).

Berdasarkan hasil pembahasan tersebut dapat disimpulkan bahwa sudah sesuai dengan teori yang dipaparkan. Pengorganisasian dibentuk untuk mencapai tujuan secara efektif dan efisien. Seperti halnya pengorganisasian di SD Negeri Bunulrejo 2 Malang ini, kepala sekolah sebagai pemegang kekuasaan tertinggi, kemudian dibantu oleh tim pengembang sekolah dan juga koordinator sekolah.

\section{Pelaksanaan Program Penguatan Pendidikan Karakter}

Kegiatan pelaksanaan program penguatan pendidikan karakter merupakan realisasi dari perencanaan yang telah ditetapkan sebelumnya. Adapun kegiatan pelaksanaan program penguatan pendidikan karakter di SD Negeri Bunulrejo 2 Malang ini ialah terintegrasi, pembudayaan, keteladanan, dan kerjasama dengan orang tua peserta didik, guna mengikuti program sekolah serta memberi dukungan atas berjalannya program penguatan pendidikan karakter tersebut. 
Fungsi pelaksanaan ialah gerakan dari kegiatan-kegiatan perencanaan dan pengorganisasian (Amtu, 2013). Penekanan dari fungsi pelaksanaan yaitu penciptaan kerja sama antar anggota organisasi serta pada peningkatan semangat kerja keseluruhan anggota guna tercapainya tujuan organisasi. Pelaksanaan lebih menekankan pada kegiatan yang berhubungan langsung dengan individu atau organisasi (Febirauqa, 2012). Kegiatan pengarahan dan bimbingan sebagai perwujudan fungsi pelaksanaan dalam manajemen memerlukan penciptaan dan pengembangan komunikasi secara efektif dan efisien. Pelaksanaan merupakan implementasi dari perencanaan dan pengorganisasian yang telah ditetapkan sehingga dapat menghasilkan output sesuai dengan yang diharapkan (Husein, 2009).

Berdasarkan penjelasan tersebut sudah sesuai dengan teori yang telah dijabarkan. Sehingga dapat disimpulkan bahwa pelaksanaan program penguatan pendidikan karakter melalui empat tahap kegiatan, yaitu terintegrasi, pembudayaan, keteladanan, dan kerjasama dengan orang tua peserta didik. Empat kegiatan tersebut saling berkesinambungan serta kontiyu, guna meningkatkan program penguatan pendidikan karakter di SD Negeri Bunulrejo 2 Malang.

\section{Pengawasan Program Penguatan Pendidikan Karakter}

Proses pengawasan program penguatan pendidikan karakter di SD Negeri Bunulrejo 2 Malang ini bersifat langsung. Artinya, kepala sekolah yang langsung mengawasi ketika kegiatan berlangsung. Kepala sekolah juga melakukan pengawasan dengan supervisi sehingga dapat mengetahui bagaimana kinerja guru dalam pembelajaran dikelas mengenai program penguatan pendidikan karakter, sehingga dapat dijadikan evaluasi agar kedepannya dapat lebih baik. Sedangkan untuk guru, guru mempunyai tanggung jawab untuk mengawasi peserta didik disaat pembelajaran berlangsung.

Pengawasan merupakan proses mendasar yang sangat diperlukan dalam suatu organisasi (Murdick dalam Fattah, 2004). Peranan pengawasan juga sangat menentukan baik atau buruknya suatu rencana, oleh karena itu harus dilakukan dengan sebaik-baiknya. Pengawasan dapat diartikan sebagai proses pengukuran dan penilaian tingkat pengelolaan kerja personil dan tingkat efisiensi penggunaan sarana kerja dalam memberikan kontribusi pada pencapaian tujuan organisasi (Amtu, 2013). Tujuan pengawasan adalah mencegah adanya kesalahan, menciptakan suasana yang transparan, dan meningkatkan kinerja organisasi (Kurniadin dan Machali, 2012).

Berdasarkan hasil pembahasan tersebut dapat disimpulkan bahwa sudah sesuai dengan teori yang dipaparkan. Pengawasan dilakukan oleh kepala sekolah dalam hal meninjau kembali program kerja yang telah dilaksanakan, yang bertujuan untuk meningkatkan dan/atau mempertahankan program kegiatan penguatan pendidikan karakter yang telah dilakukan.

\section{Evaluasi Program Penguatan Pendidikan Karakter}

Setelah dilakukannya pengawasan, maka langkah selanjutnya adalah evaluasi, guna memperbaiki program sebelumnya, sehingga kedepannya bisa menjadi lebih baik. Begitu pula dengan program penguatan pendidikan karakter di SD Negeri 2 Bunulrejo Malang. Adapun kegiatan dalam evaluasi meliputi: (1) menyusun rencana evaluasi, (2) kepala sekolah mengawasi atau melakukan supervisi, (3) mengolah dan menganalisis data, (4) mengadakan rapat, guna mencari solusi dari masalah tersebut, agar di kegiatan selanjutnya dapat lebih baik.

Informasi yang tepat dan akurat dapat diperoleh dapat diperoleh dalam kegiatan evaluasi (Wiyono dan Sunarni, 2009). Hakikat evaluasi merupakan suatu proses yang sistematis dan kontinyu guna menentukan kualitas (nilai dan arti) dari sesuatu, berdasarkan atas pertimbangan, dan kriteria tertentu dalam rangka mengambil keputusan (Kurniadin dan Machali, 2012). Tujuan dari evaluasi yaitu memperoleh dasar pertimbangan, menjamin cara kerja yang efektif dan efisien, serta memperoleh solusi atas hambatan yang dialami (Fattah, 2009).

Berdasarkan penjelasan tersebut sudah sesuai dengan teori yang telah dijabarkan. Evaluasi program pendidikan karakter memiliki empat tahapan yaitu mulai dari menyusun rencana evaluasi, mengawasi, mengolah data, serta rapat perbaikan, hal tersebut dilakukan guna menentukan kualitas daripada sesuatu, berdasarkan atas pertimbangan, dan kriteria tertentu dalam rangka mengambil keputusan. 


\section{KESIMPULAN}

Kesimpulan penelitian ini yaitu: (1) perencanaan program penguatan pendidikan karakter di SD Negeri Bunulrejo 2 Malang memiliki beberapa tahapan, yaitu observasi, rapat koordinasi, menyusun program kerja, pelaksanaan program, pengawasan, serta evaluasi. Hal tersebut dilaksanakan guna mencapai tujuan yang disepakati. Observasi dilakukan guna mengetahui bagaimana kondisi lingkungan sekolah dan peserta didik. Rapat koordinasi dilakukan untuk pemilihan tim, yang disebut tim pengembang sekolah. penyusunan program kerja dilaksanakan, dan dibantu oleh tim pengembang sekolah serta koordinator inti. Setelah itu yakni pelaksanaan program yang diikuti oleh pengawasan, guna mengetahui proses kerja sudah sesuai dengan prosedur yang ditentukan sebelumnya, dan tahap yang terakhir yaitu evaluasi, diharapkan dapat meningkatkan mutu program agar lebih baik dari sebelumnya, (2) pengorganisasian dibentuk untuk mencapai tujuan secara efektif dan efisien. Seperti halnya pengorganisasian di SD Negeri Bunulrejo 2 Malang ini, kepala sekolah sebagai pemegang kekuasaan tertinggi, kemudian dibantu oleh tim pengembang sekolah dan juga koordinator sekolah, (3) pelaksanaan program penguatan pendidikan karakter melalui empat tahap kegiatan, yaitu terintegrasi, pembudayaan, keteladanan, dan kerjasama dengan orang tua peserta didik. Empat kegiatan tersebut saling berkesinambungan serta kontiyu, guna meningkatkan program penguatan pendidikan karakter di SD Negeri Bunulrejo 2 Malang, (4) proses pengawasan program penguatan pendidikan karakter di SD Negeri Bunulrejo 2 Malang ini bersifat langsung. Artinya, kepala sekolah yang langsung mengawasi ketika kegiatan berlangsung. Kepala sekolah juga melakukan pengawasan dengan supervisi sehingga dapat mengetahui bagaimana kinerja guru dalam pembelajaran dikelas mengenai program penguatan pendidikan karakter, sehingga dapat dijadikan evaluasi agar kedepannya dapat lebih baik. Sedangkan untuk guru, guru mempunyai tanggung jawab untuk mengawasi peserta didik disaat pembelajaran berlangsung, (5) evaluasi program penguatan pendidikan karakter di SD Negeri Bunulrejo 2 Malang memiliki empat tahapan yaitu mulai dari menyusun rencana evaluasi, mengawasi, mengolah data, serta rapat perbaikan, hal tersebut dilakukan guna menentukan kualitas (nilai dan arti) daripada sesuatu, berdasarkan atas pertimbangan, dan kriteria tertentu dalam rangka mengambil keputusan.

\section{DAFTAR RUJUKAN}

Amtu, O. 2013. Manajemen Pendidikan di Era Otonomi Daerah. Bandung: Alfabeta.

Fattah, N. 2004. Landasan Manajemen Pendidikan. Bandung: PT Remaja Rosdakarya Offset.

Febirauqa, N, L. 2012.Manajemen Layanan Khusus Bimbingan dan Konseling di SMK Negeri 1 Pasuruan. Jurnal Manajemen Pendidikan, 23(5): hlm. 479.

Hasibuan, M, S. P. 2011. Manajemen Dasar, Pengertian, dan Masalah. Jakarta: Bumi Aksara.

Hidayatullah, F. 2010. Pendidikan Karakter: Membangun Peradaban Bangsa. Surakarta: Yuma Pusaka.

Isnaini, R. L. 2016. Penguatan Pendidikan Karakter Siswa melalui Manajemen Bimbingan dan Konseling Islam. Jurnal Manajemen Pendidikan Islam, 1(1): hlm. 36.

Juara, R. 2017. Implementasi Program Penguatan Pendidikan Karakter di Sekolah, (Online), (https://www. rumahjuara.com/artikel/214/implementasi-program-penguatan-pendidikan-karakter-di-sekolah), diakses 25 Januari 2018.

Judiani, S. 2010. Implementasi Pendidikan Karakter di Sekolah Dasar Melalui Penguatan Pelaksanaan Kurikulum. Jurnal Pendidikan dan Kebudayaan, 16(3): hlm.282, (Online), (https://media.neliti.com/media/ publications/138571-ID-implementasi-pendidikan-karakter-di-seko.pdf), diakses 25 Januari 2018.

Kesuma, D., Triatna, C., \& Permana, J. 2012. Pendidikan Karakter Kajian Teori dan Praktik di Sekolah. Bandung: PT Remaja Rosdakarya.

Kurniadin, D. \& Machali, I. 2012. Manajemen Pendidikan: Konsep \& Prinsip Pengelolaan Pendidikan. Jogjakarta: Ar-Ruzz Media.

Kurniawan, S. Pendidikan Karakter: Konsepsi \& Implementasinya Secara Terpadu di Lingkungan Keluarga, Sekolah, Perguruan Tinggi, \& Masyarakat. Yogyakarta: Ar-Ruzz Media.

Mulyono, M. A. 2010. Manajemen Administrasi dan Organisasi Pendidikan. Jogjakarta: Ar-Ruzz Media. 
Peraturan Presiden Republik Indonesia Nomor 87 Tahun 2017 tentang Penguatan Pendidikan Karakter. Program Penguatan Pendidikan Karakter. (Online), (http://setkab.go.id/wp-content/uploads/2017/09/Perpres_ Nomor_87_Tahun_2017.pdf), diakses 25 Januari 2018.

Purwanto, M, N. 2014. Administrasi dan Supervisi Pendidikan. Bandung: PT Remaja Rosdakarya.

Sagala, S. 2012. Administrasi Pendidikan Kontemporer. Bandung: Alfabeta.

Septiani, I. \& Wiyono, B. B. 2012. Manajemen Kegiatan Ekstrakurikuler dalam Meningkatkan Kualitas Sekolah. Jurnal Manajemen Pendidikan, 23(5): hlm 430.

Sudjana, S. 2004. Manajemen Program Pendidikan (untuk Pendidikan Nonformal dan Pengembangan Sumber Daya Manusia). Bandung: Falah Production.

Sugiyono. 2013. Metode Penelitian Pendidikan Pendekatan Kuantitatif, Kualitatif dan R\&D. Bandung: Alfabeta.

Tim Dosen Administrasi pendidikan Universitas Pendidikan Indonesia. 2012. Manajemen Pendidikan. Bandung: Alfabeta.

Ulfatin, N. 2015. Metode Penelitian Kualitatif di Bidang Pendidikan: Teori dan Aplikasinya. Malang:Media Nusa Creative.

Undang-Undang Republik Indonesia Nomor 20 Tahun 2003 tentang Sistem Pendidikan Nasional. 2010. Bandung: Citra Umbara.

Wiyono, B. B. \& Sunarni. 2009. Evaluasi Program Pendidikan dan Pembelajaran. Malang: Fakultas Ilmu Pendidikan Universitas Negeri Malang. 